\title{
1. Introduction to Islamic financial institutions
}

\section{Mohamed Ariff and Munawar Iqbal}

\subsection{INTRODUCTION}

This book is a compilation of studies of eminent scholars in the field of Islamic finance to bring to the readers a book that can be termed a foundation source book on Islamic banking or financial institutions. The book aims to bring to serious students and professional practitioners of Islamic banking a single volume of writings on the theory, principles and practices by financial institutions operating in an already viable niche banking industry growing fast in some 76 different countries. We also add at the end of the book a chapter which is an outline of possible professional accreditation and tertiary level education in Islamic banking. The contributors are eminent scholars who, having identified a need for a carefully-structured book for tertiary level training of industry professionals, then got together and produced in two years a series of studies forming the core of this book.

\subsection{ETHICAL PRINCIPLES OF PROFIT-SHARING INTERMEDIATION}

We arrange the studies in five parts that constitute this book. Three chapters are included in Part I on the important questions of financial transaction ethics that have evolved over several millennia of mankind's history. Financial ethics appear to have evolved over four millennia going back to the Mesopotamian laws relating to usury and interest rates and for financial contracting/transactions. In the first chapter of Part I, we trace the essential ethics on financial transactions as is evident in the historical writings on money, interest rates and usury. It appears that there are seven fundamental ethical principles that underlie all Islamic financial norms governing profit-risk-sharing funding practices. For example, it is revealed that there is no lending of funds if there is no immediate ownership claim 
to a class of assets to back the lending: that is no assets to back lending, no borrowing should be permitted. Modern lending is based on a promise of payment and the funds lent are not backed by explicit access to a set of assets from the start of the contracting. Another principle evident from the historical review is that there is no reward to be had in lending activities if the lender and borrower are not sharing in the risk of the venture for which the funds are put to use. Modern bank lending is based on a promise to be repaid irrespective of the consequences of the investment of the funds as justified by the very low interest charged.

It appears, in the light of current practices, that borrowers are able to access funds of savers without necessarily giving ownership claim (explicit asset-backing) to a class of assets but merely by a promise to pay the interest. This encourages profligate access to funds leading to collapse of states and of investments unsupported by asset backing. It is worthwhile to examine these human financial ethics carefully, as is done in Chapter 2 of the book, with an open mind to see how modern finance is based on principles that are far removed from the financial standards that evolved in India, Mesopotamia, China and the lands around the Mediterranean, etc.

In Chapter 3, the reader will find the foundation principles of ethics clearly espoused as Islamic guidelines as brought to the reader in this chapter. It is found that, while usury is forbidden, so are financial transactions based on not sharing in the risk of the venture for which the funds are borrowed. Sharing in the risk is a prerequisite to earning a profit share, unlike under the modern interest rate regime, where the promise to pay is based on not sharing in the risk, indeed not even providing a set of assets to back the money borrowed. What we have in modern finance is a promise to pay from the profits (or from future borrowings) a low rate of interest unconnected with the actual outcomes of the venture. Today, the sukuk bond industry has evolved over the last ten years to correct the second of the missing links in borrowing contracts by asset-based lending.

An age-old issue, still smouldering with no consensus of opinion in Islamic banking, is the concept of usury (riba) and its connection to interest rates. The interest rate is the pre-agreed claim to be rewarded - obtain an increase - without sharing in the risk of the venture nor having a set of assets to which the lender has first claim prior to the bankruptcy of the firm. In Chapter 4, a clear elucidation is made on this vexing question. The reader will learn that it is difficult to equate usury and interest as interchangeable if one looks at the historical positions of Islamic or other jurists on this question. While interest existed for millennia, so did usurious lending, which alone was banned on fear of serious punishment by such different societies as the Sung Dynasty of China, Hammurabi of Mesopotamia, the God of Moses, Jesus and of Mohammad. Then there 
is the problem of the modern banking interest rate, which to all intents and purposes is not much more than the long-run inflation rates in an economy! This low modern interest rate is designed to maintain the status quo of the value of money, for fear that without this modern banking interest rate given by banks to savers, the value of money will erode over time. Readers will learn that there is a contemporary position, a sort of consensus among Islamic scholars today, to treat usury and interest as equivalent in order to make Islamic banking palatable or saleable. The historical position on this issue has been rather different, as pointed out in this well-researched chapter.

\subsection{ISLAMIC BANKING PRINCIPLES, REGULATIONS AND GOVERNANCE}

Part II of the book is devoted to selectively introducing the regulatory and governance issues confronting Islamic financial institutions. While cursory discussions on these issues are found in various parts of the book, we make an attempt to identify three related issues in this part. In Chapter 5 , we trace the foundation principles of Islamic banking from its concept formation in the pre-1960s period to the present day. The writer traces the increasing sophistication of the products being offered today compared to those in the early period. From a simple two-tier bank deposit (twotier mudharaba contracts), more sophisticated products have appeared in recent years as evidenced by the fast developing infrastructure financing vehicle of the recent Islamic bond market instruments in several countries. The foundation principles are clearly stated in this chapter for the reader to gain the essential character of Islamic banking as being one made on two premises: risk-sharing with profit-sharing and asset ownership before funds move to the counter party, not just a promise to pay as in modern finance: these two principles enable lending to be safer, and rewards potentially tied to the usefulness of the investments for which the funds are raised.

In Chapter 6, we examine the lack of development on the important question of governance of Islamic financial institutions. Governance is more important in Islamic financial institutions because the basis of financial transactions is on ethical behaviour and disclosure standards are much more onerous to comply with the principle of gharar, the idea that the risk in a venture has to be revealed clearly upfront before entering in the contract. Ethical behaviour also requires a set of good governance standards. This chapter explains the concept of Hisbah principles for good corporate governance. The reader will find an argument to develop standards 
consistent with the much-copied OECD model of corporate governance. There are other issues discussed in this chapter on enabling legislations needed in common-law regimes to make a level playing field for Islamic banking to be licensed along with conventional banking.

The extent to which Islamic financial institutions follow the already established accounting standards and financial standards is explored in the final chapter in this part (Chapter 7). An important point is made that the compliance and disclosure standards of Islamic financial institutions are still evolving, because most institutions are not disclosing compliance. Compliance needs to be fast-tracked to protect investor interests in Islamic banking, even if the Shari'ah board supervision provides a set of initial safeguards.

\subsection{OPERATING ISLAMIC FINANCIAL INSTITUTIONS}

In Part III of the book, the reader will find three studies covering the practice aspects of three types of financial institutions including banking. In the first of these chapters (Chapter 8), we examine the critical question of whether or not Islamic banks across the world are performing as well as the conventional banks. If Islamic banking is an alternative mode of financial intermediation, no doubt replacing the interest rate of the one-sided risk-based contract with profit-shared intermediation, then it follows that the Islamic banks should by now - after 47 years of experience - perform as well as the conventional banks. So, the test is done using a large sample of Islamic banks matched with conventional banks in the same countries across the world.

What the reader will find is that the new niche Islamic banking based on eschewing usury and interest is performing as well as the conventional banks if we are to believe the test results using 16 years of data of nearly 90 banks. This finding is reassuring in that the present day Islamic banks, though the total assets of this niche industry are no more than 1 per cent of the total assets of the conventional banks, are performing as well as conventional banks. The measures we use are (i) commonly used financial ratios on performance and (ii) economic efficiency indices based on factor productivity.

In Chapter 9, we examine the performance of Islamic Index-based investments. There are about 22 so-called Islamic Index stock markettraded shares. The principles governing the choice of these investment objects are explained, while also showing how such investment funds perform relative to the conventional investment funds. Given an efficient 
market for such funds, it is the risk of funds one trades, so the rewards to either type of the funds must be the same, provided the risk is the same. That is exactly what this empirically verified behaviour of the Islamic investment fund shows.

In the last chapter in this part of the book (Chapter 10), we provide a complete description of the very recently emerging Islamic insurance (takaful) institutions. There are few important differences in this form of insurance: it has to be mutual insurance, meaning that profits must be distributed to the insured after the cost is deducted; agents do not receive commissions; and the premium is invested only in permitted investments based on Islamic profit-sharing lending. The sukuk bonds that have appeared in the last ten years will form an ideal investment vehicle for premiums of insurance companies: there is already a total of about US\$65 billion sukuk instruments. This chapter explains the different principles that govern the practice of takaful insurance.

\subsection{WHAT IS THE RIGHTFUL REWARD FOR OWNERS OF CAPITAL?}

A careful study of money shows that there has been a set of human ethics that evolved over several millennia on dealing with money. One is that exorbitant interest rates are considered as wrong by civilised societies, and by different societies as far removed as Mesopotamia, India and China which all developed laws to control usurious rates of interest until modern times. Second, interest was permitted to be charged for financial transactions so long as that interest was not usurious, that is excessive. The scriptures of the three great religions too forbid the practice of usury. Islam has a definition of usury as 'doubling and quadrupling' of the sum in a financial contract, which was a practice in ancient times: when a borrower did not return the funds borrowed on the due date, the lender would double it. Some nations legislated the rate of interest that was considered 'normal': it was fashionable to consider interest rates of 4-7 per cent as normal as recently as during the last century.

When parties to a contract charged excessive interest rates, laws were passed to annul such contracts, for example by the Sung Dynasty emperors twice, making such lenders suffer huge losses. What appears to be the human ethics in all these practices is to institutionalise protection for the borrower from the capital owners. Capital owners must not use their capital to exploit the weak, who needed money for living or for venturing. If that is the case - though Bentham would disagree - what is the right reward for parting with one's funds? 
In Part IV of the book, we explore this very ancient issue by studying the religious doctrines of the three old religions: Jewish, Christian and Islamic. In Chapter 11, we show that the Catholic Church's position appears to have shifted dramatically after the Lutheran teaching and later by the writings of Bentham in England. Bentham is well known as a writer who campaigned to remove the usury law, and succeeded much later when England rescinded the law in the nineteenth century. In Chapter 12, we identify the scriptural prescriptions on usury and interest to show that the interpretation of usury was strictly as excessive interest (akin to Islam's prohibition of doubling and quadrupling the sum borrowed). We also come to realise that usury and interest has been equated by very recent-day scholars under certain strict reinterpretation of the principles, unaware of the historical tolerance of interest: modern bank interest is unknown to earlier scholars. The reader will note that this has been a thorny problem and has been adjusted by completely making interest as also forbidden in contemporary thinking in Islamic banking. In Chapter 13, we also examine the changing attitudes to usury and interest - in general, reward for money dealers - in Christianity.

\subsection{PROFESSIONAL ACCREDITATION AND EDUCATION}

After almost five decades of the development of Islamic banking, this ethics-based experiment has resulted in a niche banking based on a profitand risk sharing mode of financial intermediation. One could describe Islamic banking as one encouraging strict codes of financial contracting thus introducing historical ethics to financial transactions. Though still having some faults as some critiques would decry this new industry, this niche banking has grown from nothing to a sizeable industry in 76 countries. There are about 500 financial institutions around the world bearing the description Islamic financial institutions with about 3 per cent (US\$3-4 trillion) of the world's total assets in Islamic banks, about US\$650 billion Islamic Index funds, about 40 insurance firms, and about 150 investment funds (mutual funds). Capital markets with publicly traded instruments have developed very fast in at least five locations in Malaysia and in the Middle East with products that are based on ethical principles ties to mankind's historical practices.

These developments mean that the industry needs trained manpower to manage this new industry. Chapter 14 traces what is available in this regard. Much more needs to be done by tertiary institutions to train such manpower as is needed for managing the Islamic banks, takaful insurance, 
mutual funds and capital markets. Chapter 14 provides information on what investment is being made in one country to provide professional accreditation to Islamic banking personnel as well as describe what needs to be taught to train people for this industry.

We believe this book provides the reader with the foundations on Islamic banking by examining the fundamental principles that constitute the theories, guide practices and provide the material for human resources training in this new niche industry. 
Mohamed Ariff and Munawar Iqbal - 9781849807937 Downloaded from PubFactory at 04/26/2023 12:03:26PM 